\title{
Teori Bigness S,M,L,XL pada Arsitektur Monumental Kota (Kasus: Paris, Dubai, dan Singapura)
}

\author{
Marchelia Gupita Sari ${ }^{\text {a, }}$, Rachmat Taufick Hardi ${ }^{\text {b, } 2}$ \\ a Program Studi Arsitektur,Universitas Pradita, Scientia Business Park, Jl. Gading Serpong Boulevard No.1, Curug \\ Sangereng, Kelapa Dua, Banten, 15810 \\ b Program Studi Perencanaan Wilayah dan Kota, Universitas Pradita, Scientia Business Park, Jl. Gading Serpong Boulevard \\ No.1, Curug Sangereng, Kelapa Dua, Banten, 15810
}

\begin{tabular}{l}
\hline Informasi artikel \\
\hline Sejarah artikel: \\
Diterima \\
Revisi \\
Dipublikasikan \\
\hline
\end{tabular}

Kata kunci:

Bigness

Koolhaas

Kota Global

Kata Kunci

\begin{abstract}
ABSTRAK
Sejarah perkembangan modernisme dalam arsitektur maupun urbanisme telah meninggalkan legasi berupa penekanan fungsional terhadap perancangan kota. Tipologi bangunan tinggi muncul karena perkembangan kebutuhan manusia sejak masa Chicago School hingga kini melanda kota-kota besar di seluruh dunia. Selain bangunan tinggi, skala bangunan atau kawasan yang didesain oleh para arsitek kerap kali sangat monumental hingga dapat dikatakan sebagai sesuatu yang terlepas dari konteks lingkungan sekitarnya. Rem Koolhaas menuangkan pikirannya mengenai keadaan deksriptif kota-kota saat ini ke dalam konsep yang diberi nama Bigness atau kemegahan. Bigness membicarakan bagaimana pengaruh skala bangunan terhadap konteks dari para arsitek dalam perancangan kota atau kawasan. Megaprojek maupun megabuilding menjadi fenomena kota di dunia dengan perwujudan bentuk beragam dalam variasinya karena menekankan kualitas sculptural. Koolhaas menggarisbawahi bahwa Generic City adalah kota tanpa identitas yang menjadi konsekusensi dari arus globalisasi, khususnya dalam arsitektur. Tujuan penelitian ini adalah untuk memahami bagaimana konsep bigness diaplikasikan pada kota-kota global. Penelitian ini menggunakan pendekatan deskriptif kualitatif dengan content analysis. Kasus yang diambil untuk makalah ini adalah kota Paris, Dubai, dan Singapura. Hasil pembahasan adalah adanya pengembangan kota dari tabula rasa atau clean state terhadap Singapura dan Dubai. Baik dari Paris, Dubai,dan Singapura memiliki kesamaan tataruang, yaitu adanya cluster tematik di mana desain berasal dari sayembara
\end{abstract} maupun starchitect

Key word:

Bigness

Koolhaas

Global City

Keyword 4

\begin{abstract}
he history of the development of modernism in architecture and urbanism has left a legacy of functionality in urban design. The typology of tall buildings arose because of the development of human needs since the time of the Chicago School to now hit major cities around the world. In addition to tall buildings, the scale of the building or area designed by architects is often so monumental that it can be provided as something independent of the context of the surrounding environment. Rem Koolhaas poured his thoughts about the current state of cities into a concept that was named Bigness or grandeur. Bigness discusses how to influence the scale of buildings against the context of the architects in the design of the city or region. Megaprojek also form a phenomenon of the city in the world with the embodiment of various shapes in its variation because it accentuates the quality of the statue. Koolhaas underlined that Generic City is a city without an identity that is a consequence of globalization, especially in architecture. The purpose of this study is to discuss how the concept of bigness is applied to global cities. This research uses descriptive qualitative with content analysis. Cases taken for this paper are the cities of Paris, Dubai and Singapore. The results of the discussion are the results of the development of the city from tabula rasa or clean conditions towards Singapore and Dubai. Both Paris, Dubai, and Singapore have spatial support, namely the existence of thematic clusters in which designs are accepted from the competition or starchitecture
\end{abstract}

Copyright (C) 2018 Universitas Widya Mataram Yogyakarta. All Right Reserved

\section{Pendahuluan}

Dewasa ini, globalisasi sebagai kenyataan dalam bidang arsitektur terasa semakin intens. Globalisasi berkaitan erat dengan internasionalisasi, tidak terkecuali praktik profesi arsitektur lintas 
negara yang berlomba-lomba memanfaatkan perkembangan teknologi terkini. Lewat perkembangan teknologi tersebut, khususnya dalam penggunaan piranti lunak dalam perancangan arsitektur, mengakibatkan bentuk-bentuk arsitektur kontemporer lebih eksploratif. Saat ini lanskap perkotaan negara-negara maju maupun berkembang di dunia dilanda megaprojek dengan investasi besar untuk membuat ikon kota yang cenderung monumental. Monumentalitas dalam arsitektur telah banyak didiskusikan karena dalam sejarah perkembangan arsitektur dunia terdapat banyak monumen arsitektur yang timeless karena disepakati dapat menunjukkan makna tertentu. Maka dari itu, makalah ini menyoroti monumentalitas dikaitkan dengan teori bigness oleh Rem Koolhaas pada tahun 1995 yang dianggap masih relevan untuk kondisi saat ini. Tujuan makalah ini untuk berusaha memahami seperti apa penerapan teori bigness pada arsitektur monumental di kota-kota global. Membaca buku S,M,L,XL Koolhaas (1995) memberikan isu apakah bigness berseberangan dengan eksisting kota, atau berusaha merangkul konteks kota. Mengenai kontekstualitas, Intenational Style maupun sistem perencanaan yang totalitarian a la modernisme kerap dikritik oleh paham postmodern.

\section{Modernisme dalam Urbanisme}

Pemikiran modernisme dalam urbanisme mencuat pada saat CIAM (Congres Internationaux d"Architecture Moderne) ke empat pada tahun 1933 yang diberi judul The Functional City. Le Corbusier sebagai penggerak memiliki gagasan ideal bahwa baik atau tidaknya sebuah kota bergantung pada fungsionalisme, mirip seperti paham yang dianut oleh gerakan arsitektur masa itu. Dituliskan Mumford (2000:85), The Athens Charter yang merupakan manifesto pertemuan tersebut merumuskan persyaratan distrik perumahan era post-war harus menggunakan lokasi terbaik dengan paparan matahari yang diatur. Untuk alasan higienitas, bangunan tidak dibangun di jalur transportasi, dan teknik yang modern harus digunakan untuk konstruksi bangunan tinggi apartemen terpisah untuk ruang terbuka hijau. Sumalyo (1997), Brolin (1980), Frampton (1980) menuliskan bahwa penerapan modernisme dalam arsitektur adalah rasionalisme, yaitu meliputi kecepatan dalam membangun (pabrikasi komponen bangunan sangat diperlukan), efisien, ekonomis. Semua diselesaikan dengan cara pragmatis.

Menurut Hall (1996) legasi modernisme yang berakar dari revolusi industri, sebuah kota mengalami pergeseran dari tempat yang bersifat publik menjadi sesuatu yang mementingkan profit sehingga perkotaan menjadi akumulasi bangunan besar yang terkesan independen atau berdiri sendiri karena skalanya (Taschen,2006). Efisiensi lahan perkotaan, perkembangan kebutuhan perkotaan, perkembangan teknologi, serta penerapan material baru sebagai hasil dari revolusi industri menurut Frampton (1980) menjadi pertimbangan bagaimana sebuah bangunan dapat memiliki skala besar dan memiliki organisasi spasial yang disusun secara vertikal.

Legasi modernisme inilah yang kemudian dikritisi oleh Rem Koolhaas, seorang teoritikus yang disebut sebagai arsitek dan urbanis postmodern oleh Taschen (2006). Kelbaugh (2008) juga menyoroti skala bangunan yang dirancang oleh para arsitek, apalagi desain oleh para starchitect dewasa ini semakin besar atau monumental. Skala bangunan yang semakin besar inilah mengakibatkan kontekstualitas dipinggirkan.

\section{Kota dengan Arsitektur Monumental Era Modern}

Kota Chandigarh didesain oleh Le Corbusier pada tahun 1950-an. Kota ini diharapkan menjadi Garden City masa setelah perang. Masterplan yang dibuat oleh Le Corbusier dengan pola grid untuk jalan dengan kecepatan tinggi, dimensi, dan organisasi superblok dengan penamaan sektor sebagai unit area pengembangan sesuai fungsinya. Terdapat pemisahan fungsi ke dalam sektor - sektor. Modul utama pada desain kota adalah satuan sektor. Capitol Complex merupakan ruang sebagai perwadahan bangunan monumental pemerintahan. Walaupun sukses dengan arsitektur monumentalnya, kritik tajam terhadap desain kota Le Corbusier diutarakan oleh Brolin (1986). Matinya street culture di India dianggap sebagai isu. Jalan yang biasanya digunakan untuk berjualan atau street vendor menjadi sepi karena bangunan-bangunan dirancang memiliki setback lebar dan aktivitas dilakukan di dalam bangunan daripada di tepi jalan.

Kota dengan pendekatan arsitektur monumentalisme lainnya adalah Brasilia. Kota berlokasi di daratan tinggi Brasilia yang dipasang sebagai ibukota Brazil pada tahun 1960. Presiden Brazil Juscelino Kubischek pada akhir 1950 memerintahkan kota untuk direncanakan dan didesain seindah mungkin hingga banyak orang yang berpendapat bahwa desain tersebut bersifat utopis. Desain perkotaan saat itu digawangi oleh Oscar Niemeyer. Pengembangan infrastruktur didesain menyerupai konfigurasi pesawat (sebagaimana hal yang berkaitan dengan 'mesin' dekat dengan bentuk arsitektur 
modern dalam Brolin, (1986)) di mana setiap section-nya melayani distrik yang berbeda, seperti pemerintahan, komersial, residensial, dan kultural. Ikon-ikon kota Brasilia diharapkan mempu menarik perhatian para pengunjung. Bangunan monumental sculptural didesain, seperti pada Three Powers Square,tempat presiden, kongres, dan pengadilan tinggi berada.

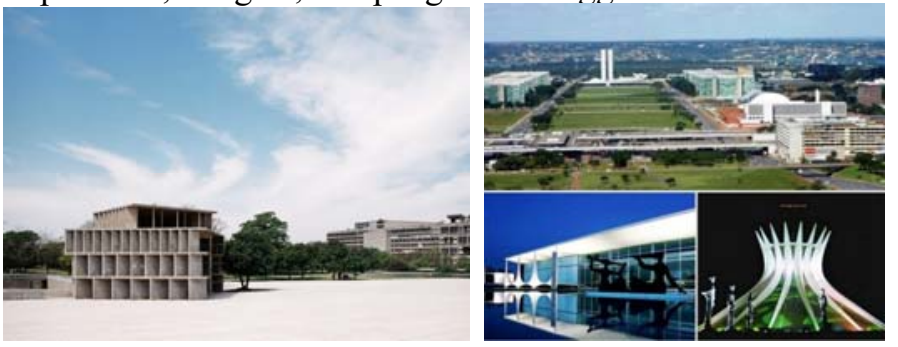

Gambar 1. Monumentalisme pada Chandigarh dan Brasilia Sumber : http://aphs.worldnomads.com/v (akses 29 Desember 2015)

Berdasarkan Ellin (1998), urbanisme dalam pendekatan postmodern dapat dikatakan sebagai urbanisme yang lebih integratif daripada pemikiran modernisme terhadap urbanisme. Misalnya saja Ley dikutip Ellin (1998:55) tentang pandangan modernisme tentang membangun social order di masyarakat, urbanisme dengan pendekatan postmodernisme berusaha menjawab tantangan bagaimana menyesuaikan dengan keberagaman masyarakat yang ada. Modernisme dalam arsitektur cenderung mencari solusi ideal daripada menyesuaikan sekitarnya, seperti bangunan tinggi atau bangunan skala monumental disisipkan di lahan tanpa mengerti konteksnya (Ellin, 1998:210) sedangkan postmodern dalam arsitektur lebih menghargai konteks seperti kebudayaan, sesuatu yang dianggap angin lalu oleh modernisme.

Dalam kumpulan esai yang diedit Kelbaugh (2008), terdapat tiga tema besar dalam urbanisme, yaitu Everyday Urbanism, New Urbanism, dan Post-Urbanism. Tema Post-Urbanism dikatakan Giometti dalam Kelbaugh (2008:196) mengatakan bahwa para Post Urbanist seperti Koolhaas percaya bahwa urbanisme telah mati, tidak mungkin untuk menciptakan kesatuan. Seperti yang diketahui, bahkan Koolhaas (1995) mengatakan bahwa kota telah berdiri sendiri-sendiri terwakilkan kemegahan bangunan-bangunan skala monumental yang tidak berdialog dengan konteksnya, bahkan 'melanggar' kode-kode peraturan arsitektural setempat. Lebih lanjut, Giometti dalam Kelbaugh (2008) menyatakan bahwa Post Urbanism seperti trendsetter atau ikon, dari praktisi urbanis. Dalam ranah arsitektur, lewat S,M,L,XL, Koolhaas (1995) menuangkan pikirannya melalui esainya, seperti Typical Plan (bagian buku skala L) sebagai implikasi dari repetisi program-program vertikal sebagai legasi modernisme. Typical plan merupakan akar dari bangunan tinggi berskala besar, di mana pergerakan manusia bergantung pada mesin elevator. Ia pun menyebut typical plan sebagai zero degree architecture. Koolhas memberikan jarak dirinya dari dogma - dogma modern tentang hubungan antara bentuk dan fungsinya. Koolhaas menganalisis dua hal, yaitu struktur perkotaan yang seperti grid dan bangunan-bangunan pencakar langit, membuat congestion. Koolhas memberikan frase hyper-efficient machine pada bangunan-bangunan bernuansa modern.

Dalam ranah arsitektur, lewat S,M,L,XL, Koolhaas (1995) menuangkan pikirannya lewat essay, seperti Typical Plan (bagian buku skala L) sebagai implikasi dari repetisi program-program vertikal sebagai legasi modernisme. Typical plan merupakan akar dari bangunan tinggi berskala besar, di mana pergerakan manusia bergantung pada mesin elevator. Ia pun menyebut typical plan sebagai zero degree architecture. Koolhas memberikan jarak dirinya dari dogma - dogma modern tentang hubungan antara bentuk dan fungsinya. Koolhaas menganalisis dua hal, yaitu struktur perkotaan yang seperti grid dan bangunan-bangunan pencakar langit, membuat congestion. Koolhas memberikan frase hyper efficient machine pada bangunan-bangunan bernuansa modern. Terdapat tiga konsep yang diusung Koolhaas dalam essay Delirious New York (Koolhaas, 1995:28), yaitu mengenai The City of the Captive Globe, yaitu : 


\section{Pemikiran Koolhaas tentang Bigness dalam konteks Urban}

Bigness menolak konteks yang ada, namun disatukan sebagai fragmen-fragmen membentuk kesatuan yang dipersepsikan sebagai suatu kota , maka Koolhaas (1995) menyatakan bigness seperti sebagai kota itu sendiri.

1. Beyond a certain critical mass, a building becomes a Big Building

2. Issues of composition, scale, proportion, detaile are now moot. The art of architecture is useless in bigness

3. In Bigness, the distance between core and envelope increases to the point where the facade can no longer reveal what happens inside. Interior and exterior architecture become seperate projects.

4. Through size alone, such buildings enter an amoral domain, beyond good or bad

5. Bigness is no longer part of any urban tissue. It exists; at most, it coexists. Its subtext fuck context.

Bigness $=$ urbanism vs.architecture

(Koolhaas, 1995:515)

\section{Kota Global}

Istilah global city atau kota global dipopulerkan oleh sosiolog Saskia Sassen pada tahun 1991 dengan kriteria yang terukur sehingga menghasilkan daftar kota global. Selain peringkat predikat Global City, terdapat Global Cities Index yang dipublikasikan jurnal Foreign Policy dan Globalization and World Cities Research Network (GaWC). Dalam S,M,L,XL, Koolhaas (1995) dan Kelbaugh (2008) menuliskan sebuah pandangan mengenai fenomena kota era postmodern. Koolhaas membahas kota-kota yang saat itu tumbuh berkembang dari kondisi tabula rasa atau clean state di beberapa bagian, yaitu New York pada tahun 1920-an, Singapura pada tahun 1960-an, dan dibahas oleh Akcan (2018), Dubai pada tahun 2000-an. Koolhaas menamai Generic City sebagai sebuah tatanan kota yang baru. Misalnya, turisme global mengakibatkan identitas kota hilang, sejarah hanya menjadi lipservice, pembangunan infrastruktur lebih ditujukan pada kendaraan, serta adanya kesamaan infrastruktur.

\section{Metode}

Penelitian ini bersifat deskriptif kualitatif dengan pendekatan metode content analysis. Bahan penelitian ini adalah teks berupa tulisan, gambar, foto-foto yang didapatkan pada laman situs internet, buku, maupun jurnal. Setelah melihat fenomena monumentalisme dalam arsitektur akibat arus globalisasi, dilakukan pemilihan kasus dengan kriteria :1)merupakan kota yang ada di daftar kota global menurut Sassen,dan masuk pembahasan Koolhaas dalam S,M,L,XL, 2) te;ah mengalami banyak perubahan akibat perkembangan kota yang pesat. Oleh karena itu, Paris sebagai kota di Eropa yang well preserved. Koolhaas (1995) pun menyinggung tentang kota-kota di Asia berbeda dengan kota Paris berkaitan dengan dampak globalisasi di antara keduanya. Paris merupakan contoh kota yang berkembang dari masa Napoleon- Haussmann, hingga saat ini terdapat distrik komersial dekat dengan aksis bersejarah, yaitu distrik La Defense. Dubai dan Singapura merupakan kota di Asia timur-tengah dan Asia tenggara yang mengalami perkembangan cepat hingga menjadi global city seperti sekarang ini. Lewat Singapore Songline dalam S,M,L,XL (1995) sejarah modernisme hingga era kontemporer Singapura menarik untuk dibahas. Kota Dubai dikatakan Akcan (2008:149) sebagai kawasan yang penuh dengan megaprojek berskala monumental seperti The World, The Palm, Creative Cluster, dan sebagainya.

Analisis data dilakukan untuk mencari hubungan bigness pada arsitektur monumental di kotakota tersebut dengan cara komparasi. Pertama, pengumpulan data mengenai karya tulis Koolhaas, menemukan isu dan mengkategorikannya, menguraikan hasil temuan, dan menarik kesimpulan dari analisis untuk dijadikan pemahaman awal aplikasinya pada desain arsitektur monumental. 


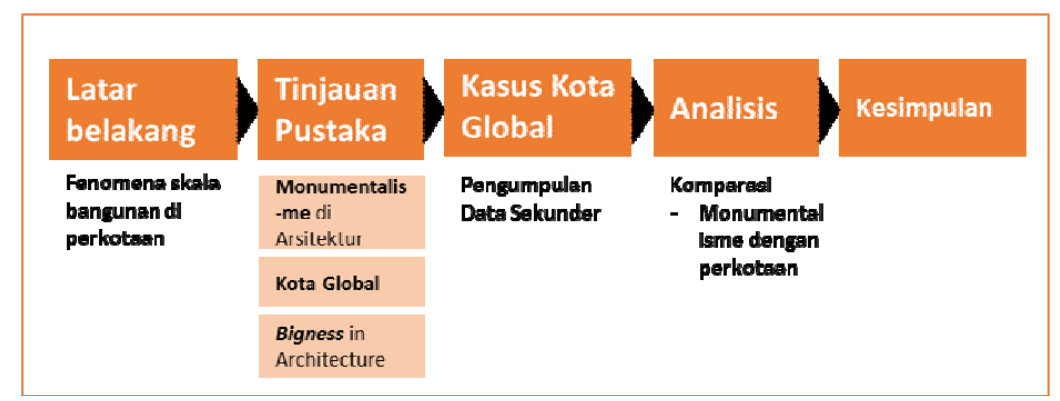

Gambar 2. Alur Pemikiran

\section{Hasil dan pembahasan}

Transformasi kota Paris pada era Haussmann hingga Paris masa kini : Greater Paris - La Defense

Berdas Salmaan (1971), Paris menghadapi tekanan akibat revolusi industri dan revolusi-revolusi lainnya (revolusi pemerintahan). Megaproyek Napoleon III dengan para perancang dan penata kota. Dikatakan Hall (1996), Proyek Haussmann yang berlangsung pada tahun 1853 sampai dengan tahun 1870 mencakup seluruh aspek dari perencanaan urban, baik di pusat kota Paris maupun di distrikdistrik sekelilingnya, yaitu jalanan dan jalan raya, taman-taman umum, saluran pembuangan dan saluran air, fasilitas kota, dan monumen publik. Peraturan dan batasan yang diberlakukan oleh pihak berwenang menghasilkan tipologi bangunan dan ruang jalan Paris khas era Haussmann. Pada tahun 1925, Le Corbusier mengusulkan konsep kota Plan Voisin menandai Paris dengan berdirinya maketmaket skyscraper di tengah perkotaan Paris dengan menghiraukan keberadaan monumen-monumen kota. Pendekatan yang dibawa oleh Le Corbusier diistilahkan tabula rasa tanpa menghiraukan konteksnya. Hajer (1999:140) menuturkan bahwa Koolhas menunjuk paradoks pemikiran urban kontemporer, yaitu adanya keinginan para pemangku kepentingan kota untuk tetap mempertahankan atau preservasi inner city, namun juga ingin berkembang untuk menyamakan kedudukan dengan kotakota lainnya.
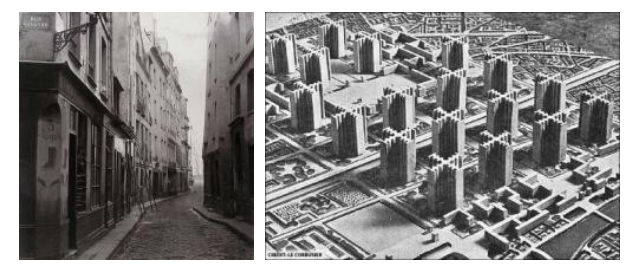

Gambar 3. Paris era Haussmann dan Rancangan Le Corbusier Sumber :

http://sedulia.blogs.com/sedulias quotations/2011/10/barthelme -le-corbusier-and-paris.html (akses 29 Desember 2015) 


\section{Monumentalitas pada Kota Paris : Triangle Building dan La Defense}

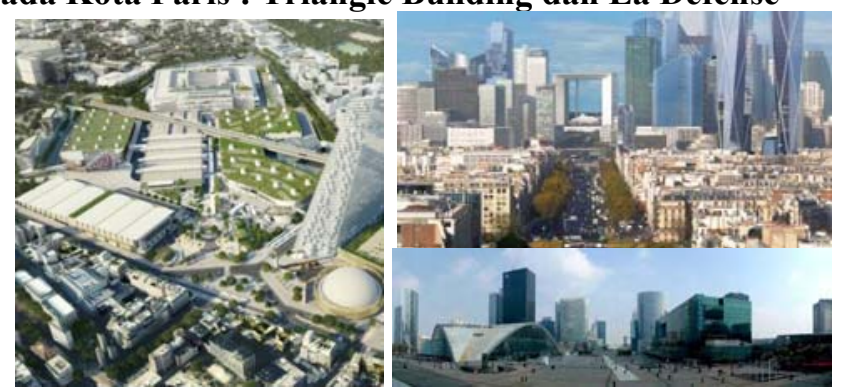

Gambar 4. La Defense dan Triangle Tower

Sumber :

France.fr (akses 4 Januari 2020)

Karena keadaan ekonomi yang membaik, serta keinginan kota Paris untuk internationalisasi, terdapat kebutuhan untuk mengembangkan area di luar region Paris tanpa menjadi sangat kontras dengan pusat kota yang historis dan menjadi kawasan pusaka, menurut Scicolone (2014:4) senada dengan Glaeser (2011). Pada tahun 1958, pembangunan dan komersialisasi wilayah La Defense berada di bawah tanggung jawab perusahaan pemerintah EPAD (Etablissement Public pour l“Amenagement de la region de La Defense). La Defense awalnya memiliki fungsi sebagai wilayah perkantoran dan perdagangan, lambat laun EPAD sebagai pengelola La Defense menjadikan kawasan tersebut sebagai wilayah yang mengintegrasikan antara pusat perkantoran dan perumahan dengan aksesibilitas yang sangat baik oleh angkutan umum massal dan ketersediaan jalan tol.

Perkembangan bangunan tinggi di La Defense diawali pada tahun 1964 dan 1969. Pada tahun 1964 masterplan yang diajukan mengadaptasi CIAM. Terdapat peraturan bahwa tipe bangunan yang diperolehkan adalah bangunan perkantoran 25 lantai dan $75.000 \mathrm{~m}^{2}$ bangunan apartemen antara 5-12 lanta (Roberts,2011:6). Pada perkembangan selanjutnya, pada tahun 1970 dibangun metro link antara La Defense dengan Place de leetoile yang berlokasi di ujung Avenue des Champs-Elysees. EPAD mengambil kebijakan untuk menggandakan ruang komersial ke $1.55 \mathrm{juta}^{2}$. Pada tahun 1972, EPAD memutuskan untuk menghilangkan larangan ketinggian bangunan dan meningkatkan luas gross floor area.

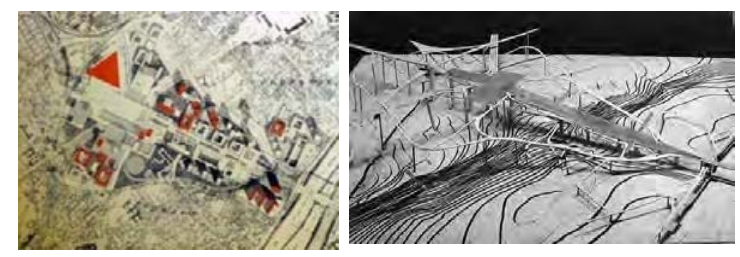

Gambar 5. Masterplan La Defense

Sumber : awp.fr/projects/master-plan-strategic-plan

Penggandaan ruang komersial tersebut dilakukan untuk memenuhi permintaan untuk ruang komersial dari perusahaan besar ataupun perusahaan multinasional. Towers pun dibuat lebih besar karena kebutuhan ruang yang semakin besar. Pada tahun 1978, setelah terhenti 30 tahun, La Defense meneruskan pertumbuhannya, apalagi dengan permintaan bangunan perkantoran dengan lantai yang besar dan fleksibel (Roberts,2011). Pembangunan ini direferensikan sebagai generasi kedua bangunan tinggi mega building terus bermunculan. Pada tahun 1982 EPAD mengorganisasikan sayembara untuk mendesain pandangan aksis dari Paris. Grande Arche oleh Otto Von Sprecklensen dipilih untuk dibangun di ujung aksis historis Paris. Bangunan ini menjadi ikon aksis historis sekaligus sebagai landmark kawasan La Defense.Robert (2011) telah menyusun kualitas signifikan La Defense sebagai Grand Project kota Paris. Pertama, adalah prinsip openness. Pembangunan La Defense tidak dihambat peraturan ketinggian bangunan. Karena tidak adanya larangan arsitektural, maka bangunan-bangunan bisa direnovasi atau didemolisi sesuai dengan keinginan pasar. La Defense tetap mempertahankan konektivitas dengan kota bersejarah 
Paris. Konsep lainnya yang disinggung oleh Robert (2011) adalah mixed use dan surface ludique, yaitu adanya ruang-ruang publik.

Yang menjadi sorotan tentang La Defense yang banyak berubah dari masterplan yang secara cermat dirancang dibandingkan Haussmanian Paris, perbedaan yang mencolok ada pada level pedestrian ways menurut Robert (2011). Skala bangunan-bangunan terlalu monumental atau kurang proporsional pada skala manusia. Permukaan bangunan di eye-level tidak menarik dan monoton sehingga nampak berdiri sendiri-sendiri.

\section{Monumentalisme di Kota Dubai}

Dubai memulai pembangunan besar-besaran ketika dipimpin oleh Sheik Mohammed yang mengagendakan variasi pemasukan ekonomi ketika cadangan minyak akan habis, salah satunya adalah dengan pengembangan real estate. Elshashtawy (2010:124) mencatat bahwa pada tahun 2005 real estate merepresentasikan 24.2 persen GDP Emirate dan proyek senilai jutaan dolar secara aktif diagendakan. Dubai menjadi terkenal akan megaproject seperti Burj Khalifa dan Dubai Land.Dikatakan Miraftab (2015) bahwa negara atau kota-kota di semenanjung Arab menjadi sepakat dan menjalankan kebijakan urbanisme kota yang bersifat top-down, berskala besar, dan institusional.

Dilansir dari situs www.rudi.net, Dubai dikatakan sebagai „laboratorium arsitek dunia" karena pada era saat ini Dubai menjadi tempat di mana arsitek bereksperimen dengan projek-projek skala besar mereka, seperti yang dipaparkan Kanna dan Keshavarzian dalam Roldan (2013:12). Starchitecture telah menjadi elemen krusial pada pencapaian transformasi perkotaan yang unik sebagai branding kota Dubai menjadi global city.

\section{Starchitecture}

Pada masa kontemporer ini, arsitek official pemerintah UAE atau yang disebut Levebre (2003) para urbanist memakai wacana-wacana dalam keradikalan bentuk arsitektur pada sebuah projek. Firma arsitek terkenal menjadi langganan pemerintah untuk megaprojek sebuah kota (Miraftab, 2015).

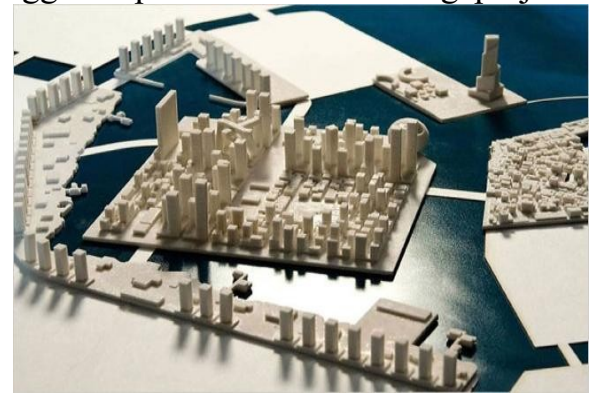

Gambar 6 Waterfront City

Sumber : oma.eu/projects/waterfront-city

Waterfront City merupakan contoh ideal dari Generic City menurut Koolhas. Pulau buatan hasil reklamasi berukuran $1,310 \mathrm{~m} \times 1,310 \mathrm{~m}$ yang dibagi menjadi 25 city block tradisional yang memperbolehkan desain rasional, dapat direpetisi, seperti legasi pemikiran modernisme dalam arsitektur. Generic City dalam desain ini membuktikan bahwa arsitek berperan dalam pembentukan kawasan dalam skala besar dengan konsep-konsep atau teorinya sendiri. Seperti pada Foster, konsepnya tentang Dubai Creative Authority, sebuah zona di mana tema pengembangannya adalah sektor industri kreatif. 


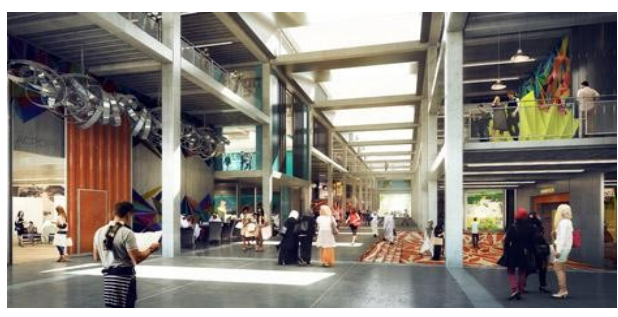

Gambar 7 Dubai Creative Cluster

Sumber : dcca.gov.ae/

\section{Singapura}

Singapura telah berkembang semenjak adanya permukiman vernakular Kampung Glam, masterplan kota yang dirancang oleh pemerintah Inggris sebagai strait settlement, hingga adanya arah pembangunan vertikal yang dirancang oleh otoritas setempat, yaitu melalui kebijakan pemerintah. Merangkum dari Widodo (2003) mengenai modernisme di Singapura, terdapat Singapore Improvement Trust (SIT) bentukan Inggris dan Housing Board Development (HBD). Setelah mendapat kemerdekaannya pada tahun 1960, tahun 1965 HBD telah membuat mass housing dengan statistika menyebutkan bahwa $85 \%$ warga Singapura sudah tinggal di hunian vertikal.

Hunian vertikal merupakan solusi paling rasional untuk menampung penduduk yang kian bertambah jumlahnya sesuai dengan perkembangan kota. Selain itu, hunian vertikal dianggap mampu mengatasi masalah perkotaan, seperti kekumuhan di dalam kota. Untuk menanggapi isu kontektualitas, HBD dengan Holland Drive-nya berusaha untuk menghadirkan kontekstualitas kawasan dengan desain fasad bangunan yang tidak monoton. Saat itu, DP architect sebagai biro arsitek besar kerap membuat hunian-hunian vertikal.

\section{White Zone Singapura}

Seiring dengan berjalannya waktu, konsep white site dikenalkan oleh URA (Urban Redevelopment Authority) pada tahun 1995 yang memberikan developer fleksibilitas dalam penggunaan lahan terbeli dari pemerintah sehingga developer bebas menentukan kegunaan lahan tersebut serta menentukan besarnya gross floor area mengakibatkan pembangunan mengarah vertikal. Fleksibilitas perubahan fungsi juga dimungkinkan pada saat melihat keadaan pasar saat bangunan atau kawasan. Koolhaas (1995) mengangkat Singapura sebagai bagian penting dalam S, M, L, XL karena Singapore Songline seperti menjadi suatu bagian tersendiri dalam buku tebal tersebut. Ia mengkritisi perencanaan seperti Tabula Rasa dan tersentral dari pemerintah tanpa mengindahkan konteks lingkungan.

\section{Analisis Data}

\begin{tabular}{|c|c|c|c|}
\hline Ciri-ciri & Paris & Dubai & Singapura \\
\hline $\begin{array}{l}\text { - Tumbuh dan berkembang pesat, } \\
\text { “Jika telah padat, maka ia akan } \\
\text { berkembang }\end{array}$ & $\begin{array}{l}\text { The Greater Paris dan La Defense } \\
\text { sebagai pemekaran wilayah dan } \\
\text { memisahkan diri dari kota historis } \\
\text { yang dipreservasi }\end{array}$ & $\begin{array}{l}\text { Adanya reklamasi pulau buatan } \\
\text { sebagai pemekaran wilayah }\end{array}$ & $\begin{array}{l}\text { Adanya reklamasi sebagai } \\
\text { pemekaran wilayah }\end{array}$ \\
\hline $\begin{array}{l}\text { - Berasal dari Tabula Rasa (clean } \\
\text { state) }\end{array}$ & $\begin{array}{l}\text { Mempertahankan elemen kota } \\
\text { Grand Axis dan } \\
\text { bangunan-bangunan lama } \\
\text { A la Koolhaas : selektif memilih } \\
\text { bangunan yang memiliki nilai } \\
\text { kultural lebih }\end{array}$ & $\begin{array}{c}\text { Arsitektur vernakular tidak } \\
\text { menonjol. Pembangunan kota } \\
\text { dari padang Pasir }\end{array}$ & $\begin{array}{l}\text { Banyak bangunan lama } \\
\text { yang } \\
\text { dihancurkan untuk membuat } \\
\text { hunian vertikal }\end{array}$ \\
\hline $\begin{array}{l}\text { - Bangunan bergerak tumbuh ke } \\
\text { vertikal, bukan horizontal } \\
\text { - Fungsi } \\
\text { bangunan di perkotaan } \\
\text { didominasi hotel, area } \\
\text { berbelanja, maupun fasilitas } \\
\text { hiburan } \\
\text { lainnya }\end{array}$ & 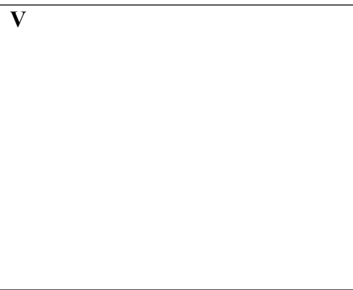 & $\mathbf{V}$ & $\mathbf{V}$ \\
\hline
\end{tabular}




\begin{tabular}{|c|c|c|c|}
\hline Ciri-ciri & Paris & Dubai & Singapura \\
\hline $\begin{array}{l}\text { Adanya sisipan bagian } \\
\text { kota yang muncul karena } \\
\text { tidak sepenuh direncanakan } \\
\text { dengan matang }\end{array}$ & $\begin{array}{l}\text { Perubahan } \\
\text { masterplan }\end{array}$ & $\begin{array}{l}\text { Adanya fleksibilitas perencanaan } \\
\text { dengan munculnya Cluster- } \\
\text { cluster tematik }\end{array}$ & $\begin{array}{l}\text { Direncanakan secara matang } \\
\text { Adanya fleksibilitas } \\
\text { perencanaan dengan } \\
\text { munculnya White } \\
\text { Zone }\end{array}$ \\
\hline $\begin{array}{l}\text { Pelestarian hanya sebagai agenda } \\
\text { wisata, banyaknya facadism } \\
\text { bangunan bersejarah dan } \\
\text { dijadikan atraksi, menarik }\end{array}$ & & & \\
\hline
\end{tabular}

\begin{tabular}{|c|c|c|c|}
\hline & Paris & Dubai & Singapura \\
\hline $\begin{array}{l}\text { Peraturan pemerintah tentang } \\
\text { Gross Floor Area dan } \\
\text { ketinggian bangunan }\end{array}$ & $\begin{array}{l}\text { Fleksibel (Kluster } \\
\text { tematik) }\end{array}$ & $\begin{array}{l}\text { Fleksibel (Kluster } \\
\text { tematik) }\end{array}$ & $\begin{array}{l}\text { Fleksibel (White } \\
\text { Zone) }\end{array}$ \\
\hline \multicolumn{4}{|l|}{$\begin{array}{l}\text { Guideline elemen desain } \\
\text { kontekstual pada site sekitar } \\
\text { pada kluster tematik/white } \\
\text { zone }\end{array}$} \\
\hline Starchitect & $\begin{array}{l}\text { Koolhaas, Rogers, } \\
\text { Nouvel, Spreckelse } \\
\mathrm{n}\end{array}$ & $\begin{array}{l}\text { Foster, Koolhaas, } \\
\text { Hadid, }\end{array}$ & Tange, Safdie, \\
\hline $\begin{array}{l}\text { Monumentalitas dari para } \\
\text { starchitect }\end{array}$ & Kawasan (kluster) & Kawasan (kluster) & Kawasan (kluster) \\
\hline
\end{tabular}

\section{Simpulan}

Dari studi literatur studi kasus, didapatkan bahwa gejala bigness pada kota-kota tersebut sudah terlihat dari variabel yang diturunkan. Adanya perbedaan yang diperhatikan adalah menurut Glaeser (2011) Paris merupakan kota yang well preserved dengan adanya pemisahan antara kawasan yang dikembangkan sebagai area ekonomi dengan area kota historis sejak era Haussmann. Walaupun, ia memandang Paris menjadi kota yang mahal akibat pembatasan ketinggian bangunan. Pandangan Koolhaas (1995) terhadap Paris dengan kompetisi Grand Mission Axe adalah menyeleksi nilai signifikan bangunan lama, kemudian membuat masterplan yang monumental. Di Dubai, skala desain yang dibuat oleh starchitect dapat meliputi distrik atau kluster kawasan, sebagaimana yang dilakukan oleh Foster (DCCA) dan Koolhaas (The Waterfront City).

Bigness merupakan sebuah teori deskriptif dengan ciri fenomena-fenomena yang dideskripsikan Koolhaas, terutama ketika melihat monumentalitas bangunan dan kawasan yang dipandang kurang dapat berdialog dengan sekitarnya. Adanya suatu guideline arsitektur tentang nilai lokal kawasan dapat membantu agar starchitect atau para post-urbanist membuat sesuatu yang ikonik dan masif, namun kurang cocok diterapkan di kota tersebut. Apalagi jika suatu proyek tersebut adalah proyek sayembara besar dari pemerintah kota.

\section{Referensi}

Ellie, Nan.1996. Postmodern Urbanism. New York: Princeton Architectural Press

Fox, Daniel. 2008. Rem Koolhaas : An Architecture of Innovation. Volume 16-2008 Paper 8

Glaeser, L.Edward. 2011.Triumph of the city.Macmillan.

Hajer, Maarten. 1999. The Generic City. Theory, Culture\&Society 1999. Vol 16 (4) 
Ikhwanuddin, 2005. Menggali Pemikiran Posmodernisme dalam Arsitektur. Yogyakarta : Gadjah Mada University Press

Kelbaugh,Douglas.2008.Writing Urbanism.London and New York : Routledge

Koolhaas, Rem. 1995. S, M, L , XL. New York : The Monacelli Press

Robert, Nick.2011. La Défense: From Axial Hierarchy to Field Condition, modul perkuliahan dapat diakses di http://www.aplusu.org/files/small-book-110627-small.pdf

Taschen,(2006).Architectural Theory from the Renaissance to the present..Taschen

Yaari, Monique.2008. Rethinking the French City: Architecture, Dwelling, and Display After 1968.

Yu, Shing Ming. 2000. "White” Site Valuation: A Real Option Approach. Fifth Annual Asian Real Estate Society (AsRES) conference

http://www.grand-paris.j1l.fr/grand-paris-project/id/31

http://www.telegraph.co.uk/news/worldnews/europe/france/ 4980639/Grand-Paris-Architects-revealplans-to-transform- French-capital.html

http://www.jonesday.com/files/Publication/b579ff2c-0e2d-4 069-a3fe-

bb4628233fcf/Presentation/PublicationAttachment

/27dc3502-2f37-4117-8f95-c8b0ad3ea4c1/UAE\%20free\%2 0zones.pdf

https://www.ura.gov.sg/uol/land-sales.aspx?p1=find-gls-site \&p2=ura-sale-sites 